\title{
ABORSI: ANTARA TEKS DAN REALITAS (TELAAH ATAS PROBLEMATIKA ABORSI DALAM PERSPEKTIF ISLAM DAN REALITAS SOSIAL)
}

\author{
Abdul Wasik \\ Sekolah Tinggi Agama Islam (STAI) At-Taqwa Bondowoso \\ Email : abdul_wasik80@yahoo.co.id
}

\begin{abstract}
The issue of abortion is still a serious problem in the social realities of community life, including in our country in Indonesia. As stated by the Indonesian Child Protection Commissioner (KPAI) for the Health and Drug Sector, it provides data on illegal abortion in the world or in Indonesia. In 2016, there were around 56 million women with abortions, in 2018 it decreased to 42 million, while in Indonesia the number was around 2 million cases of abortion. In this paper systemically will discuss various basic Islamic ethical foundations regarding human reproduction, then an investigation of the legal-ethical position of abortion in various Islamic perspectives, which in this case is more emphasized on the results of the ijtihad of the four Imam Schools in the Indonesian context the opinions of Imam Shafi $i$ and the MUI were more dominant. The answer to this case of abortion is that abortion is not only underestimated, it is only lawful and haram, but it must be considered between the text and the social reality so that the Al-Qur'an and $\mathrm{Al}$-Hadith truly become Rahmatan Lil 'Alamin's guidelines for humans.
\end{abstract}

Keywords: Abortion, Ijtihad, and Social Interaction

\section{PENDAHULUAN}

Dalam tradisi islam, fiqh memiliki peran sentral sebagai instrumen hukum untuk mengatur kehidupan seseorang dalam masyarakat muslim. Mereka memerlukan perangkat hukum yang karakternya sudah tidak lagi murni tekstual normatif (Al-Qur'an atau Al-Hadits), akan tetapi sudah terstruktur menjadi sebuah pranata hukum aplikatif manusia (fiqh).

Dengan demikian, maka fiqh dikodifikasikan untuk mengelola secara operasional keseluruhan aktifitas manusia, mulai dari persoalan ritual keagamaan, sampai masalah-masalah profan, baik yang berkaitan dengan politik, sosial, ekonomi maupun budaya atau yang lebih dekat dikenal Hablum Min Allah Wa Hablum Min An-Nas (hubungan manusia dengan tuhannya dan hubungan manusia yang satu dengan manusia lainnya).

Banyak anggapan dari kaum pembaharu bahwa secara mayoritas, hukum yang terkandung dalam Al-Qur'an ataupun Al-Hadits adalah 
didominasi oleh hukum-hukum kemanusiaan daripada hukum-hukum ketuhanan. Dan bisa dibuktikan seberapa banyak dalil-dalil Al-Qur'an atau AlHadits yang menceritakan tentang hubungan manusia yang satu dengan manusia yang lainnya daripada dalil-dalil yang menjelaskan hubungan manusia dengan tuhannya. Begitupun hubungan manusia yang satu dengan sesamanya tidaklah melulu perbuatan baik namun kejelekannyapun selalu melekat dalam pergaulan sehari-hari, perbuatan aborsi misalnya. Hal ini diakibatkan adanya interaksi social walaupun factor yang menyebabkan aborsi berbeda. Adakalanya disebabkan karena gangguan kesehatan kehamilan (reproduksi perempuan), terkadang karena kurang gizi, dan ada juga karena pergaulan bebas yang rentan dilakukan.

Sebagaimana yang disampaikan oleh Komisioner Perlindungan Anak Indonesia (KPAI) Bidang Kesehatan dan NAPZA memberikan data aborsi illegal di dunia ataupun di Indonesia. Pada tahun 2016 tercatat sekitar 56 Juta perempuan aborsi, 2018 menurun menjadi 42 juta, sementara di indonesia jumlahnya sekitar 2 juta kasus aborsi dengan berbagai hal yang melatar belakanginya.

Oleh karena itu dalam paper ini secara sistemik akan dibahas berbagai landasan-landasan dasar etis Islam tentang reproduksi manusia, lalu penelusuran kedudukan hukum-etis aborsi dalam pelbagai perspektif Islam yang dalam hal ini lebih ditekankan pada hasil ijtihad empat Imam Mazhab di mana dalam konteks ke-Indonesia-an lebih dominan diterapkan pendapatpendapat Imam Syafi i, dan MUI melalui fatwa-nya sebagai lembaga formal Islam di Indonesia yang menjadi bagian penting dalam pemberian pertimbangan hukum etis seputar masalah aborsi ini.

\section{LANDASAN ETIS ISLAM TENTANG REPRODUKSI MANUSIA}

Dalam konteks ke-Indonesia-an perilaku aborsi barangkali merupakan tindakan yang seakan legal apabila berdasarkan UU No. 23 tahun 1992 tentang kesehatan yang dinyatakan bahwa "dalam keadaan darurat sebagai upaya untuk menyelamatkan jiwa ibu hamil dan atau janinnya, dapat dilakukan tindakan medis tertentu". Dan dalam kenyataannya banyak tindakan aborsi itu dilakukan secara illegal dan banyak mengakibatkan kematian bagi ibu. Sehingga aborsi yang sebenarnya ditunjukkan untuk kemaslahatan berbagai pihak justru seringkali memunculkan masalah-masalah baru.

Aborsi sebagai problem dalam konteks keindonesiaan tidak hanya menjadi perdebatan dalam ruang hukum positif, namun perdebatan dilematis dalam konteks keagamaan. Berdasarkan konsep undang-undang positif 
maupun hukum Islam, hak hidup manusia adalah hak asasi setiap individu yang wajib untuk dilindungi. Perdebatan aborsi sebagai pertentangan seputar "prioritas etis" mengutamakan hak hidup ibu ataukah janin, merupakan perdebatan yang pelik di antara para ahli Fiqh sebagai interpretasi tentang awal batas kehidupan manusia, yakni apakah kehidupan itu dimulai sejak ditiupkan ruh (40 hari), atau di atas 40 hari, ataukah sejak pembuahan ataukah sejak masih dalam bentuk air mani. Hal-hal inilah yang kemudian menjadi pokok perdebatan seputar aborsi dalam Islam.

Adapun aborsi yang merupakan istilah bahasa Inggris dalam bahasa Arab disebut dengan isqotul hamli (pengguguran kandungan dengan usia tua) dan oleh para pakar bahasa Arab kontemporer di ubah menjadi istilah alIjhadh, yakni pengguguran kandungan ketika usia janin masih muda. Dalam term kedokteran dimaknai sebagai pengeluaran buah kehamilan ketika masih berbentuk kecil, yakni berat janin masih kurang dari 100 gram atau usia kandungan kurang dari 20 hari, sehingga tidak bisa hidup di luar rahim. Keperbedaan istilah ini hanya pada keperbedaan bahasa, yang secara esensi dari kedua istilah dan sudut pandang ini adalah bahwa pengguguran kandungan (aborsi) yang sudah melampaui usia kandungan tua akan memberikan risiko yang lebih besar terhadap kesehatan dan keselamatan si ibu, sehingga usia kandungan ini kemudian menjadi dasar pokok pertimbangan dalam hukum-etis- boleh tidaknya aborsi.

Secara kejadian, abortus bisa terjadi pertama secara spontan, yakni keguguran yang tidak sengaja sebelum fetus berkembang atau sebelum lahir. Berdasarkan klasifikasi tingkatan proses maka terdapat beberapa tahap aborsi yaitu : abortusimenes, keadaan yang masih bisa diselamatkan abortus insipiens, suatu keadaan di mana abortus tidak mungkin di cegah. Abortus inkompletus, yaitu keguguran tetapi masih tertinggal sisa-sisa buah kehamilan di dalam rongga rahim. Keguguran semacam ini dalam kaidah fiqhiyyah dinamakan dengan al-isqotul al'afwu, yakni sebagai aborsi yang secara hukum taklif di maafkan. (Badri, dkk.2002:242).

Dan kedua aborsi dapat terjadi dengan sengaja (abortus provocatus), yakni proses terjadinya aborsi dilakukan secara sengaja. Dalam hal ini dikategorikan dalam dua macam; aborsi artifisialis therapicus, yakni aborsi yang dilakukan oleh dokter berdasarkan gejala medis (isqatul al-Daruri) guna menyelamatkan nyawa ibu dan aborsi procatus cri-minalis, yakni aborsi yang dilakukan dengan sengaja tanpa indikasi secara medis (isqatul al-Ihktiyari), tindakan aborsi ini biasanya dilakukan untuk meniadakan hasil hubungan seks di luar nikah ataupun kehamilan yang tidak dikehendaki. 
Janin dalam term Arab jelas berarti sesuatu yang diselimuti, yakni sesuatu yang akan terbentuk dalam rahim perempuan dari saat pembuahan sampai kelahiran. Berdasarkan ayat-ayat yang menjelaskan tentang awal kejadian manusia. Proses kejadiannya manusia berasal dari tanah, air yang hina (sperma) air yang terpancar (orgasm) dan setetes mani yang ditumpahkan ke dalam rahim, dari genitika laki-laki dan perempuan, dari saripati air mani yang disimpan dalam rahim, dari segumpal darah, dari tulang belulang, yakni segumpal daging yang membentuk tulang belulang, dari daging tulang yang di bungkus dengan daging, dan dari makhluk lain. (Badri,2002:246).

Dalam QS. Al-Mu'minun: 12-14

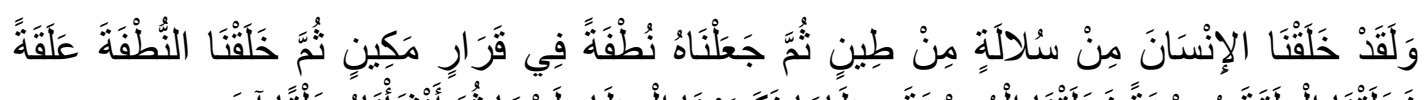

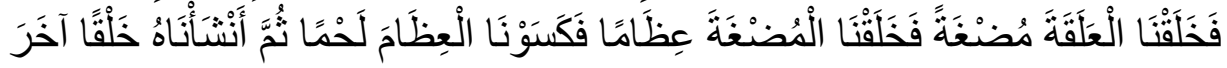

"Dan sesungguhnya Kami telah menciptakan manusia dari suatu saripati (berasal) dari tanah, Kemudian Kami jadikan saripati itu air mani (yang disimpan) dalam tempat yang kokoh (rahim), Kemudian Kami jadikan saripati itu air mani (yang disimpan) dalam tempat yang kokoh (rahim)." (QS. Almu'minun: 12-14)

Berdasarkan ayat al-Qur'an ini bahwa awal kejadian manusia itu berawal dari rahim Ibu yang berupa nutfah yang berusia 40 hari yang berupa 'alaqoh 40 hari, berupa mudghah 40 hari sampai menjadi makhluk yang berbentuk manusia dan kemudian di tiupkan ruh di dalamnya. Hal ini diperkuat hadits Nabi Muhammad SAW:

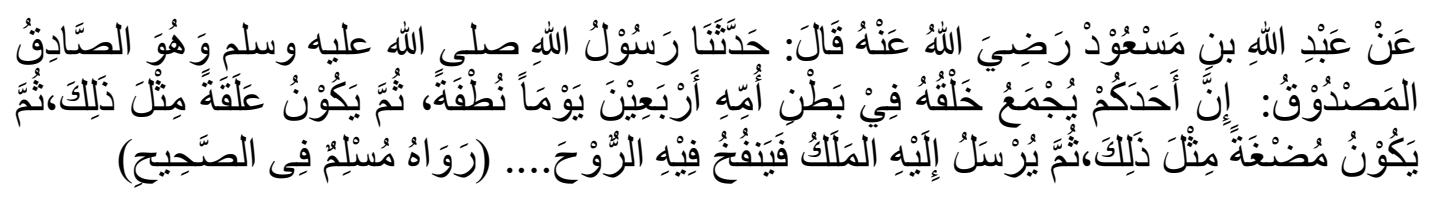

"Dari Abdullah bin Mas'ud RA, dia berkata: telah berkata kepada kami Rasulullah Shallallahu 'Alaihi wa Sallam, dan dia adalah orang yang jujur lagi dipercaya:"Sesungguhnya tiap kalian dikumpulkan ciptaannya dalam rahim ibunya, selama 40 hari berupa nutfah (air mani yang kental), kemudian menjadi 'alaqah (segumpal darah) selama itu juga, lalu menjadi mudghah (segumpal daging) selama itu, kemudian diutus kepadanya malaikat untuk meniupkannya ruh, ...." (HR. Muslim) 
Keterangan dalam al-Qur'an dan Al-Hadits ini diperkuat oleh Imam Ash-Shobuny ( tt.VI:71), bahwa proses perkembangan mudghah dalam minggu keempat dan kedelapan sudah terbentuk semua alat-alat tubuh manusia dan susunan alat-alat tubuh utama sehingga pada hitungan bulan kedua segumpal darah itu kemudian berubah menjadi semakin besar kepala, badan, wajah, telinga, hidung dan mata, sedangkan peniupan ruh yang disebutkan dalam hadits tersebut merupakan hasil interpretasi dari ayat (khalqon akhoor) dari surat al-Mukminun sebagai proses peniupan kepadanya. Namun demikian untuk masalah ruh sendiri dalam al-Quran dengan tegas dinyatakan sebagai urusan Tuhan.(QS. Al-Isra:85). Dan Imam Suhaely menyimpulkan secara sederhana pemahaman tentang ruh sebagai dasar jiwa dan jiwa itu tersusun dari ruh yang menyatu dengan jasad. Hal ini di dasar kan pada kerangka ijtihad syar`i bukan falsafi dan thaba $i$ (naluri kemanusiaan). (Ibnu kastir, tt: 62)

\section{ABORSI DALAM PELBAGAI PERSPEKTIF-ISLAM(PERSPEKTIF EMPAT IMAM MAZHAB)}

Imam An-Nawawi dalam kitabnya Syarh Shahih Muslim, Juz XVI, (tt:91) Ketika memperbincangkan aborsi sebagai tindakan hukum, maka Fiqh sebagai produk hukum seringkali menjadi hasil rujukan hampir setiap persoalan umat Islam. Dalam kasus aborsi pertanyaan pertama yang paling mungkin dikemukakan adalah apakah perempuan yang diperkosa boleh menggugurkan kandungannya? karena pemerkosaan sebagai tindakan brutal seringkali menimbulkan banyak trauma psikologis yang luar biasa kepada sang korban. Alasan pengguguran kandungan akibat pemerkosaan semacam ini ketika dilakukan di atas umur 4 bulan (seratus dua puluh hari), hukumnya adalah haram, karena janin pada saat yang demikian telah menjadi makhluk hidup. Dan dasar dari al-Qur'an surat al-Isra 'ayat 33,

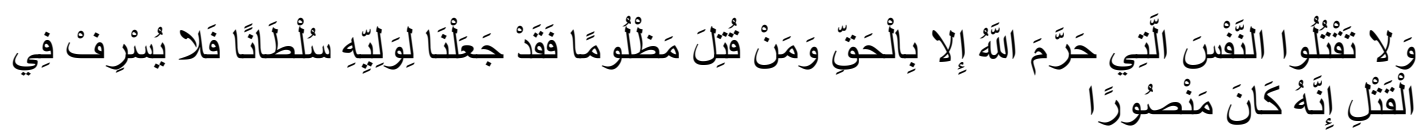

"Dan janganlah kamu membunuh jiwa yang diharamkan Allah (membunuhnya), melainkan dengan suatu (alasan) yang benar. Dan barang siapa dibunuh secara lalim, maka sesungguhnya Kami telah memberi kekuasaan kepada ahli warisnya, tetapi janganlah ahli waris itu melampaui batas dalam membunuh. Sesungguhnya ia adalah orang yang mendapat pertolongan. (QS. Al-isro: 33) 
Dalam ayat ini sangat jelas menegaskan bahwa membunuh manusia dalam kondisi apapun tetap saja hukumnya haram, meskipun membahayakan ibunya.

Perilaku pengguguran dalam masa usia kandungan di bawah usia 4 bulan di antara para ahli Fiqh masih terdapat perdebatan, misalnya sebagaimana yang disampaikan Imam Al-Ghazali (tt: Juz II; 53) melarang pengguguran (aborsi) dalam semua tahapan pertumbuhan janin, tanpa adanya tafsil (klasifikasi) terhadap usia janin dalam kandungan. Walaupun demikian Imam ar-Ramli dari mazhab Syafi i juga justru menganggap aborsi boleh dilakukan dengan klaisifikasi yang berbeda tergantung pada usia janin. Sedangkan aborsi yang diakibatkan oleh hamil dari zina, sejumlah ulama Syafi i membolehkan.

Para ahli Fiqh "salaf" sepakat bahwa aborsi (isqath al-haml/al-ijhad) adalah dilarang setelah lewat dari empat bulan dari kehamilan, karena usia kehamilan pada saat tersebut diyakini sebagai batasan telah terbentuknya manusia secara penuh, karena pada saat tersebut ruh telah ditiupkan ke dalamnya. Dari kejelasan dasar hadits ini pula dengan tegas para ulama fiqih menyatakan bahwa aborsi pada kandungan yang sudah berusia 120 hari (4 bulan) hukumnya haram dan merupakan tindakan pidana pembunuhan terhadap makhluk yang sudah bernyawa. dan bagi pelaku pembunuh nya akan dikenakan diyat (denda) sebagai pembunuh.

Berbeda dengan pendapat kalangan ulama tersebut di atas, kehamilan yang diakibatkan oleh hasil pemerkosaan baik secara individual, maupun massal, dalam kajian fiqh kontemporer terdapat berbagai pandangan. Sebagaimana yang dikutip dalam majalah al-Buhuts al-Fiqhiyyah al-Muashirah, kajian fiqih kontemporer terbitan Riyadh Saudi Arabia, No XVII, Tahun V dan dalam Rubrik Masail fi al-Fiqh, (2001:204). Hal ini juga dikutip oleh Husein Muhammad dalam Fiqh Perempuan Refleksi Kiai atas Wacana Agama dan Gender,(2001:166).

Dasar nilai etis hukum yang digunakan dalam kebolehan aborsi oleh karena keadaan yang dilematis bukan hanya persoalan tempo waktu kehamilan semata. Hal ini berdasarkan kaidah fiqh, antara lain:

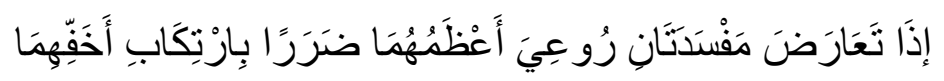
"Apabila terdapat dua kemudharotan maka menjaga kemudhartan yang lebih besar dengan mengerjakan kemudhoratan yang lebih ringan." (mahmud, 1998: 95) 
Berdasarkan kaidah ini mengambil pilihan buruk dari yang paling buruk ketika terdapat tuntutan pemilihan satu dari kedua alternatif tersebut. Sehingga berdasarkan pendapat kalangan kontemporer ini, pengguguran kandungan didasarkan atas pertimbangan unsur yang lebih maslahah (kebaikan) antara menggugurkan dan tidak menggugurkan.

\section{SANGSI DAN DOSA DALAM PERTIMBANGAN ETIS SEPUTAR PERSOALAN ABORSI}

Mengenai sangsi (diyat) bagi pelaku pembunuhan termasuk aborsi di dalamnya terdapat perselisihan pendapat di antara para imam mazhab. Menurut Imam Maliki baik Mudgah (segumpal darah) ataupun Alaqah (segumpal daging) ketika digugurkan, maka akan dikenakan sangsi, namun berbeda dengan imam Syafi'i yang menyatakan bahwa sangsi hanya diberikan ketika sudah berbentuk sebagai manusia sempurna, yakni sesudah ditiupkan nya ruh dalam jasad.( Ibnu Rusd,tt:312). Dari perselisihan ini, maka menjadi jelas pula bahwa tindakan aborsi yang dilakukan sebelum umur 4 bulan memberikan akibat perselisihan pula.

Pertimbangan waktu sebelum ditiupkannya ruh di dalam jasad janin bukan merupakan pedoman kebolehan menggugurkan kandungan. Pendapat ini diantaranya disepakati oleh Ibnu Hajar dalam kitab al-Tuhfah, al-Ghazali dalam kitab Ihya Ulum al-Din, Muhamad Saltut dalam kitab al-Fatwa, mereka memberikan alasan bahwa Janin (embrio) walaupun belum ditiupkannya ruh dalam jasad sudah dinyatakan sebagai keberadaan kehidupan yang harus dihormati.(Ad-Dhimyathi, Juz 4:130-131).

Dari uraian-uraian tersebut di atas maka jelas bahwa dasar ketidakbolehan aborsi yang dikategorikan sebagai tindakan pembunuhan itu oleh al-Ghazali adalah sejak bertemunya sel sperma dengan ovum dan sudah terjadi proses pembuahan. Sedangkan beberapa ulama yang membolehkan aborsi diantaranya adalah ishaq al-Maruzy, Syikh Muhamad Ramli dan mayoritas Ulama mazhab Hanafi dengan menambahkan penjelasan waktu sebelum janin berusia 120 hari. (Badri, 2005: 254)

Imam al-Ghazali menganalogikan proses pertemuan sperma laki-laki ke dalam rahim itu sebagai proses akad (ijab dan qabul), artinya bahwa pemerkosaan ataupun guna-guna merupakan tindakan yang tidak di-kehendaki dan disepakati bersama, maka jelas akad semacam ini adalah batal demi hukum. Hal yang menarik untuk di ambil benang merah dari para pendapat ulama-ulama ini adalah antara aborsi dengan kesehatan, yakni bahwa proses aborsi merupakan tindakan yang tidak normal terhadap organ reproduksi 
perempuan dalam hal ini dapat mem-bahayakan diri sendiri yang dalam etika Islam sangat jelas mendapatkan larangan. Hal ini berdasarkan sebuah Kaidah Fiqh: لا ضرر ولا ضرار artinya tidak boleh membahayakan kepada diri sendiri atau membahayakan kepada orang lain. (mahmud, 1998: 89)

Pemaparan tersebut di atas dapat dipahami sebagai hasil ijtihad dan keputusan hukum para ulama "salaf" yang dipertimbangkan secara menyeluruh dari berbagai aspek baik secara sosiologis, psikologis, sosial ekonomi, politik, maupun kesehatan dan kesehatan sosial pada saat itu. Namun demikian, titik tekan yang diberikan oleh para ulama ini lebih pada persoalan transenden "ruh janin" oleh karena proses putaran waktu kandungan. Padahal ada hal lain yang dalam perkembangan kontemporer menjadi pertimbangan etis yang sangat penting pula sebagai dasar hukum aborsi, artinya bahwa pengharaman aborsi boleh jadi tidak haram karena ada kondisi-kondisi yang darurat, yakni ketika sesuatu yang dilarang itu tidak dikerjakan akibatnya akan membinasakan jiwa, seperti pertama ketika menyelamatkan nyawa sang ibu yang sedangkan mengidap penyakit membahayakan, ataupun janin sang akan dilahirkan menurut keterangan media kalau dilahirkan akan mengidap penyakit seumur hidup atau membutuhkan biaya perawatan yang sangat tinggi. Kedua adalah ketika hamil yang dikandung itu akibat tindakan pemerkosaan atau korban guna-guna sebagai hasil hamil yang tidak dikehendaki serta tindakan persetubuhan tidak disepakati.

Berdasarkan maqosid asy-Syariah untuk kemaslahatan umat hal ini sangat dilematis antara tinjauan sebagai perbuatan zina dan tidak, sehingga tindakan ini sebagai tindakan yang dilakukan secara tidak sadar, yakni dihukumi subhat.( Hakim,tt: 65). Dan pertimbangan etis yang didasarkan hadits Nabi atas tindakan hukum yang subhat adalah gugur-nya hukuman. Ketiga adalah ketika karena himpitan ekonomi pada dampak sosial yang serius, (Badri: 2457). Kasus yang demikian ini didasarkan pada kondisi darurat dengan kaidah Fiqh bahwa ketika ada dua buah risiko, maka seyogyanya diambil risiko yang paling ringan.

\section{ABORSI DALAM PERSPEKTIF KEPUTUSAN MUI (FATWA)}

Dalam Munas MUI pada tahun 1983 dinyatakan bahwa konsep awal kehidupan adalah sejak mulainya proses pembuahan, maka pengguguran sejak proses pembuahan itu adalah haram. (Sarapung, dkk. Editor,1999:166). Alasan ini didasarkan kepada kaidah Fiqh:

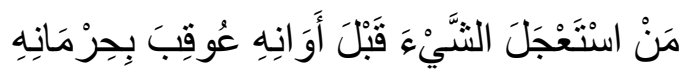


"Barang siapa mendahulukan sesuatu yang belum pada waktunya justru akan berakibat buruk (gagal) untuk dilaksanakannya. (mahmud, 1998:167) dan baca juga Fiqh Realitas, Respon Ma'had Aly terhadap Wacana Hukum Islam Kontemporer (Abu Yazid,2005).

Dalam Musyawarah Nasional VI Majelis Ulama Indonesia yang berlangsung pad tanggal 23-27 Rabiul Akhir 14211 / 25-29 Juli 2000 pada pembahasan mengenai aborsi berlatar belakang pada problem tindakan aborsi (al-Ijhadh), yakni pengguguran janin tanpa alasan medis sebelum nafkhu ar-ruh (peniupan ruh pada jasad janin), Direktorat Jenderal Bimbingan Masyarakat Islam dan Penyelenggaraan Haji Departemen Agama RI, dalam buku Himpunan Fatwa Majelis Ulama Indonesia, pada bagian Keputusan Fatwa tentang Aborsi, (2003: 259-263) memberikan landasan hukum pada al-Qur'an yakni surat al-Mukminun (23) ayat 12-14, surat al-Hajj (22) ayat ke 5, sedangkan landasan haditsnya diriwayatkan oleh Imam Bukhari pada bahasan awal penciptaan manusia, dan hadits pada bahasan kisah para nabi dan penciptaan adam serta anak cucunya, dan beberapa hadits lain yang menjelaskan tentang proses penciptaan anak-anak Adam di dalam perut ibunya. Hal ini bisa Lihat Fatwa MUI Pusat tentang Aborsi (2005).

Janin dalam perspektif MUI dinyatakan sebagai makhluk yang memiliki kehidupan yang dihormati (hayah muktarom) yang meng-gugurkannya berarti menghentikan kehidupan yang telah ada dan ini hukumnya adalah haram berdasarkan beberapa dalil-dalil shahih, diantaranya adalah:

1. Al-Qur'an surat al-Isra' ayat 33 yang menyatakan tidak diperbolehkan membunuh jiwa yang diharamkan kecuali ada alasan yang benar,

2. Ataupun dasar hukum pada pendapat para fuqoha tentang permasalahan aborsi sebelum nafkhu ar-ruh. Beberapa hukum yang dipertimbangkan adalah pertama, boleh (mubah) secara mutlak (tanpa harus ada alasan medis, menurut ulama Zaidiyah sekelompok ulama Hanafi, sebagian ulama Syafi i, serta sejumlah ulama Maliki dan Hambali. Kedua, Mubah karena ada alasan medis (uzur) dan makruh jika tanpa ‘uzur menurut ulama Hanafi dan sekelompok ulama Syafi i. Ketiga, menyuruh secara mutlak menurut sebagian ulama Maliki. Keempat, haram menurut pendapat mu 'tamad ulama Maliki. (Bayan li an-Nas min al-Azhar asy-Syarif, Juz II, hal.256)

3. Menurut Ulama Imam al-Ghazali dari kalangan mazhab Syafi i, jika nutfah (sperma) telah bercampur (ikhtilath) dengan ovum dan siap menerima kehidupan (isti'dadul al-qabul li al-hayah) maka merusaknya dipandang sebagai tindak pidana (jinayah) ini berarti haram melakukannya.

4. Membolehkan aborsi sebelum nafkhu ar-ruh dapat menimbulkan aneka dampak negatif, di samping dampak positif dengan dasar kaidah fiqhiyah:

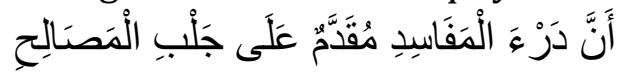


"Menghindarkan kerusakan itu diutamakan daripada, mendatangkan kemaslahatan."

Kaidah Fiqhiyah berikutnya:

الضَّرُورَاتُ تُبِيحُ الَْحْظُورَاتِ

"Bahwa keadaan darurat membolehkan hal-hal yang diharamkan sebelumnya".

\section{KETETAPAN MUI TENTANG PERSOALAN ABORSI}

Dengan berbagai pertimbangan hukum-hukum tersebut di atas, maka Majelis Ulama Indonesia melalui keputusan Musyawarah nasional VI tahun 2000 yang dipimpin oleh Prof. Umar Shihab dan Dr. Din Syamsudin Direktorat Jenderal Bimbingan Masyarakat Islam dan Penyelenggaraan Haji Departemen Agama RI, Himpunan Fatwa Majelis Ulama Indonesia, pada bagian Keputusan Fatwa tentang Aborsi, (2000: 265), menetapkan hal-hal yang berkenaan dengan Aborsi sebagai berikut:

1. Mengukuhkan keputusan Munas Ulama Indonesia tanggal 28 Oktober 1983 tentang kependudukan, kesehatan dan pembangunan.

2. Melakukan aborsi sesudah nafkhu ar-Ruh (lebih dari 40 hari) hukumnya adalah haram, kecuali jika ada alasan medis, seperti untuk menyelamatkan jiwa si Ibu.

3. Melakukan aborsi sejak terjadinya pembuahan ovum walaupun sebelum nafkhu ar-ruh, hukumnya haram, kecuali ada alasan medis atau alasan lain yang dibenarkan oleh syari'ah Islam.

4. Mengharamkan semua pihak untuk melakukan, membantu dan mengizinkan aborsi. (baca: Direktorat Jenderal Bimbingan Masyarakat Islam dan Penyelenggaraan Haji Departemen Agama RI, Himpunan Fatwa Majelis Ulama Indonesia, pada bagian Keputusan Fatwa tentang Aborsi: 265).

Keputusan MUI pada tahun pada tahun 2000 tersebut di atas kemudian dibahas ulang dan mendapatkan penyempurnaan dengan munculnya fatwa MUI 2005 tentang Aborsi adalah sebagai berikut; Pertama adanya ketentuan umum:

1. Darurat, yaitu suatu keadaan di mana seseorang apabila tidak melakukan sesuatu yang diharamkan maka ia akan mati atau hampir mati.

2. Hajat adalah suatu keadaan di mana seseorang apabila tidak melakukan sesuatu yang di haramkan maka ia akan mengalami kesulitan besar.

Kedua adalah ketentuan hukum, bahwa: 
1. Aborsi adalah hukumnya haram sejak terjadi implantasi blastosis pada dinding rahim ibu (nidasi).

2. Aborsi dibolehkan karena terdapat uzur yang melatarbelakanginya, baik yang bersifat darurat ataupun hajat.

Keadaan darurat adalah yang berkaitan dengan kehamilan yang membolehkan aborsi adalah: Pertama, Perempuan hamil yang menderita sakit fisik berat seperti kangker stadium lanjut, TBC dengan caverna dan penyakit fisik berat lainnya yang telah ditetapkan oleh team ahli kedokteran. Kedua, Dalam keadaan di mana kehamilan mengancam nyawa si ibu.

Sedangkan keadaan hajat adalah yang berkaitan dengan kehamilan yang membolehkan aborsi adalah: Pertama, Janin yang dikandung dideteksi menderita cacat genetik yang kalau kelak lahir akan sulit disembuhkan, Kedua, Kehamilan akibat pemerkosaan yang ditetapkan oleh team yang berwenang yang didalamnya terdapat antara lain keluarga korban, dokter, dan ulama, dan Ketiga, Kebolehan aborsi tersebut pada dua point awal harus dilakukan sebelum janin berusia 40 hari. Dan secara tegas dalam Fatwa MUI tersebut dinyatakan tentang hukum keharaman aborsi di lakukan pada kehamilan yang terjadi akibat zina. (baca: Keputusan Pengurus Majelis Ulama Indonesia, Fatwa MUI Pusat tentang "Aborsi" berisi tentang Klipping Pers Republika 21 Mei 2005, beberapa ayat Al-Qur'an tentang kejadian manusia, Fatwa MUI no.1/ Munas VI/MUI/2000, Diktum Fatwa MUI 28 Oktober 1993, Fatwa MUI no.4 tahun 2005, Sekretariat MUI DIY Yogyakarta, 2005.)

\section{ANALISIS TEKS DAN REALITAS}

Setelah menelaah berbagai hasil ijtihad dan berbagai pandangan sebagaimana di atas, maka penulis memahami antara pendapat para Imam mazhab yang empat dan juga para tokoh kontemporer terdapat perbedaan pertimbangan etis, oleh karena perbedaan ruang dan waktu kejadiannya. Persoalan yang sederhana misalnya adalah kemudahan perempuan dalam melakukan aborsi di mana di masa sekarang jauh lebih mudah dan mendapatkan dukungan situasi atas lemahnya sistem kontrol nilai dari agama maupun kontrol sosial, maka Fatwa MUI ataupun pendapat dari per-timbangan berbagai lembaga masyarakat dan tokoh kon-temporer sebenarnya mempunyai tantangan etis yang sama dan kemudian menjadi bagian penting sebagai legalitas bagi masyarakat.

Dalam pemahaman penulis hasil ijtihad dari para ulama khususnya Imam Mazhab serta ulama "salaf" dan juga lembaga formal MUI tersebut hampir semuanya memakai landasan hukum dan pertimbangan etis pada Al- 
Qur'an dan Al-Hadits di samping pertimbangan etika sosial yang berada di sekitarnya. Maka dalam posisi yang demikian, posisi hukum-etisnya yang dihasilkan oleh Ulama "salaf" itu sudah sesuai dengan masanya, sedangkan fatwa MUI paling tidak yang mengembangkan dasar nilai (universal values) dalam pengambilan hukum aborsi mencoba kontekstual dengan aspek dan nilai perkembangan secara kontemporer. Dalam kondisi demikian ini ternyata fatwa dan hukum apalagi pertimbangan nilai etis menjadi sangat lentur dalam perubahan dinamika waktu dan tempat.

Pandangan pribadi penulis terhadap persoalan aborsi ini didasarkan pada pendekatan hukum dan etis, maka ada beberapa hal yang mampu dikemukakan, yakni secara hukum aborsi pada dasarnya tidak boleh dilakukan karena hal itu menyalahi aturan hidup, memotong jalur kehidupan seseorang yang belum pada waktunya. Hal ini menjadi semakin jelas bahwa setiap janin secara umum dan alamiah akan menjadi manusia, ketika tindakan aborsi itu dilakukan, maka sesungguhnya tindakan tersebut melanggar hukum pada kasus pidana pembunuhan dan tidak menghargai hak-hak asasi manusia. Hukum ini berlaku umum, kecuali ketika terdapat kondisi exception, yang kemudian secara pertimbangan etis menjadi pedoman penting di dalamnya.

Dalam kasus aborsi, boleh dilakukan ketika terdapat situasi yang tidak normal. Ketidaknormalan ini menguatkan pendapat Penulis pada pemaparan di atas disebabkan oleh faktor penyebab terjadinya kehamilan, yakni proses yang mengakibatkan kehamilan (semisal pemerkosaan), dan ataupun ketidaknormalan yang di prediksi berdasarkan data valid medis pada proses setelah kelahiran janin yang akan dilahirkan (seperti terdapat cacat pada janin dan lain-lain). Pendapat ini nampaknya senada dengan keputusan Pengurus Fatayat NU yang mengharamkan tindakan aborsi kecuali ketika terdapat beberapa kondisi yang memberikan rukhsah al-Hukm yang didasarkan pada beberapa kondisi tertentu.

Pengurus Fatayat NU Sebagai organisasi yang consent dalam wilayah ke-perempuan-an, memberikan pendapat etis berdasarkan keputusan dalam lokakarya pada tanggal 27-28 April 2001 terhadap pembolehan aborsi ketika terdapat indikasi-indikasi sebagai berikut; Pertama, Indikasi medis, seperti terancam nya nyawa ibu, hal ini boleh dilakukan sebelum dan bahkan sesudah ditiupkan nya ruh, yakni ketika usia janin 120 hari. Kedua, Indikasi sosial ekonomi yang berkaitan langsung dengan keberlangsungan hidup. Ketiga, Indikasi politik yang menjadikan perempuan tidak memiliki pilihan lain kecuali melakukan aborsi. Dan Empat, Indikasi psikologis yang memposisikan 
perempuan untuk melakukan tindakan aborsi semacam pemerkosaan. hal ini dilakukan sebelum ditiupkan nya ruh ke dalam jasad janin.

Prinsip pertimbangan etis yang pertama adalah awal kehamilan yang tidak normal adalah seperti kasus pemerkosaan. Hubungan persetubuhan yang dilakukan itu batal demi hukum karena ada unsur pemaksaan dalam tindakan yang mengakibatkan kehamilan. Secara etis hubungan itu sama sekali tidak diinginkan oleh korban pemerkosaan (perempuannya), maka karena prinsip pertama ini, hamil oleh karena paksaan pemerkosaan boleh dilakukan aborsi.

Kedua, adalah prinsip karena tidak normal dalam keberlangsungan hamil. Artinya proses kelahiran anak itu, ketika tetap dipaksakan maka akan terjadi kematian pada pihak Ibu. Dalam kondisi demikian ini, maka pertimbangan etis nya adalah mengambil risiko yang paling ringan, yakni menyelamatkan nyawa ibu lebih didahulukan ketimbang menyelamatkan janin yang akan dilahirkan. Pertimbangan etis yang diberikan oleh Gamal Serour dalam The Future of Human Reproduction (1998) bahwa aborsi dapat dilakukan ketika diperuntukkan penjagaan kesehatan sang ibu ataupun ketika terdapat hal yang serius terhadap anak yang akan dilahirkan. (Gamal Serour:1998)

Ketiga adalah ketidaknormalan hasil kehamilan yang akan dilahirkan, artinya ada cacat pada calon anak yang akan dilahirkan sehingga kelahiran itu sendiri akan berakibat buruk terhadap keberlansungan sang anak karena cacat yang telah diderita sejak dalam kandungan dan atau bayi ini dalam keberlangsungannya akan banyak membutuhkan biaya yang besar yang justru akan memberatkan secara psikis maupun materi bagi semua pihak.

Berbagai pertimbangan etis tersebut di atas kaitannya dengan masalah usia kandungan, Penulis lebih sepakat dengan pertimbangan tokoh dari kalangan hanafiyah yang tidak mempertimbangkan usia kandungan ketika unsur security (keamanan) ibu itu mampu dipertanggungjawabkan. Hal ini didasarkan pada akibat hukum dan pertimbangan etis atas akibat dari kehamilan itu tidak dibatasi waktu, artinya akibat pemerkosaan secara psikis akan selama membekas. Begitupun keselamatan sang ibu akibat kehamilannya (kesehatannya), dan juga bayi yang akan dilahirkan dalam kondisi cacat juga tidak akan berubah oleh perubahan waktu. Maka dari sini keputusan hukum dan etis berlaku tetap.

Pendapat-pendapat ini apabila dikomparasikan dengan pendapat para ulama empat mazhab (ulama"salaf"), akan sangat berbeda, karena hukum yang dihasilkan berdasarkan pendapat Imam Mazhab termasuk Syafi i di dalamnya tidak terdapat pengecualian pada kondisi apa yang membolehkan aborsi 
setelah usia kandungan lebih dari 4 bulan. Secara mutlak mereka mengharamkan pengguguran kandungan baik oleh karena kondisi terpaksa apalagi tidak terdapat kondisi darurat. Pendapat ini berbeda dengan Para tokoh Mesir memberikan tanggapan terhadap persoalan aborsi yang dilakukan setelah usia kandungan lebih dari 4 bulan adalah diperbolehkan ketika ada suatu kondisi darurat seperti keberlangsungan kandungan justru akan membahayakan sang ibu. (Sa`diyah Shaikh:19)

Pada dataran lain yang tidak kalah pentingnya adalah penanganan atas pembolehan tindakan aborsi oleh pihak yang berwenang, artinya secara teknik kewenangan yang berhak membantu proses tindakan aborsi (karena unsur keamanan ibu), secara hukum formal penting untuk dibentuk pihak kedokteran yang secara resmi ditunjuk oleh pemerintah yang diberikan otoritas untuk membantu melakukan aborsi. Legalitas ini tentu diberikan dengan berbagai ketetapan etis yang dirumuskan baik secara aturan etis agama, maupun medis dan bahkan ketentuan hukum. Dan usulan yang telah di lontarkan oleh MUI dengan adanya keterlibatan Dinas Menteri Kesehatan dalam pengawasan dan pemberian izin aborsi dengan kerjasama dengan para tokoh agama, nampaknya menjadi rekomendasi positif serta penting untuk keberlanjutan persoalan aborsi yang menjadi masalah urgen di bumi Nusantara ini.

\section{PENUTUP}

Hampir mayoritas agama-agama memberikan batasan bahwa tuhan-lah menciptakan semua kehidupan. Dan embrio merupakan sosok manusia yang telah mempunyai hak asasi nya sejak masa konsepsi, dan aborsi sebagai tindak pembunuhan yang melawan kodrat kehidupan.

Pertanyaan yang dimunculkan adalah apakah janin itu sosok yang telah mempunyai hak yang sama dengan janin yang saat telah dilahirkan, ada kalangan yang menyatakan bahwa embrio yang dilahirkan sama dengan seseorang yang hidup. Bahwa aborsi yang dilakukan sebelum usia kandungan lebih dari 4 bulan (120 hari) mayoritas para pemikir adalah membolehkan, walaupun tidak terdapat kondisi yang sangat mendesak sekalipun, namun pada persoalan aborsi di atas usia kandungan 4 bulan.

Polemik ini dalam Penulis nyatakan sebagai elestisitas pada hukum dan nilai etis Islam. Kasus perdebatan panjang atas aborsi sebagai perkembangan sains dan teknologi mendapatkan jawaban yang tidak secara hitam dan putih (halal, haram) dari dasar hukum Islam, namun banyak menerapkan pertimbangan konteks yang mendasarinya. Yakni bahwa aborsi dapat dihukumi haram, makruh, mubah dan bahkan wajib. Bioetika dalam perspektif 
Islam merupakan pandangan secara etis atas suatu produk hukum yang dinilai secara fleksibel dan sangat arif sesuai dengan konteks berjalannya suatu itu terjadi.

\section{DAFTAR RUJUKAN}

Abu Bakar al-Dimyathi (tt), I'anah al-Thalibin. Semarang: Toha Putra.

Abu Yasid, Dr., LL.M, editor (2005), Fiqh Realitas, Respon Ma 'had Aly terhadap Wacana Hukum Islam Kontemporer. Yogyakarta: Pustaka pelajar.

Al-Gazaliy, Abu Hamid, Muhammad bin Muhammad (tt), Ihyaa' 'Ulum Al-Diin. Beirut: Dar Al-Ma'rifah.

Al-Hafidz Ibnu Katsir, 2006. Tafsir Ibnu Katsir, Beirut: Dar Al-Kutub

Ali As-Shobuny, 2001. Rowa'iul Bayan Tafsir Ayatil Qur'an, Beirut: dar al-kutub

Azrul Azwar MPH, Prof. Dr. dr. Ketua Pengurus Harian PKBI, Kompas, tanggal 26 Agustus 2000.

Direktorat Jenderal Bimbingan Masyarakat Islam dan Penyelenggaraan Haji Departemen Agama RI (2003), Himpunan Fatwa Majelis Ulama Indonesia, pada bagian Keputusan Fatwa tentang Aborsi. Jakarta: Depag RI Bagian Proyek Sarana dan Prasarana Produk Halal.

Elga Sarapung dkk, editor (1999), Agama dan Kesehatan Reproduksi. Jakarta: Pustaka Sinar Harapan Kerjasama dengan The Ford Foundation.

Gamal Serour (1998), Reproductive Choice: A Muslim Perspective in the Future of Human Reproduction. Oxford: Calrendon Press.

Hariri, Ibrahim Moch. Mahmud. tt. "Al-Madkhol Ila Al-Qowaid Al-Fiqhiyah AlQulliyah".'Iman: Dar Imar.

Husein Muhammad (2001), Fiqh Perempuan Refleksi Kiai atas Wacana Agama dan Gender. Yogyakarta: LKiS.

Komisi Fatwa MUI (2005), Fatwa MUI Pusat tentang Aborsi. Yogyakarta, Sekretariat MUI DIY.

(tt), al-Mustashfa min Ilmi al-Ushul. Beirut: Dar Ihya' at-Turath al-Arabi.

Majalah al-Buhuts al-Fiqhiyyah al-Muashirah, kajian fiqih kontemporer, Riyadh Saudi Arabia, No XVII, Tahun V. 